дитиною свого місця в світі («Я»-соціальне, цілісне як основа самодостатньої особистості, коли виникає гармонія серця, розуму і волі (Г. Костюк).

\title{
Література:
}

1. Максименко С.Д. Проблеми прогнозування психічного розвитку дитини. Проблеми девіантної поведінки: історія, теорія, практика : Матеріали Всеукраїнської науково-практичної конференції (2527 листопада 2002). Київ: Міленіум, 2002. С. 3-29.

2. Прийняття дитиною цінностей: посібник / Т.О. Піроженко, I.I. Карабаєва, С.О. Ладивір, Л.І. Соловйова та ін., за ред. Т.О. Піроженко. Київ: Видавничий Дім «Слово», 2018. 240 с.

DOI https://doi.org/10.30525/978-9934-588-80-8-1.20

\section{ПАТОГЕНЕЗ ДЕПРЕСИВНИХ СТАНІВ ТА ЇХ ВПЛИВ НА ПСИХОСОМАТИЧНЕ ЗДОРОВ'Я}

\author{
Чистовська Ю. Ю. \\ кандидат психологічних наук, доиент кафедри психології \\ Черкаський національний університет імені Богдана Хмельницького \\ м. Черкаси, Україна
}

Загальновизнано, що виникнення депресій мультикаузально, тобто широкий спектр біологічних, середовищних та психологічних факторів можуть зробити свій внесок в генезис депресивних розладів. За останні роки з'явилось багато різних концепцій, що намагаються вияснити роль цих факторів впливу. I з самого початку не відчувалося нестачі в роботах, що намагалися підвести спільну теоретичну базу під окремі напрямки досліджень, але останнім часом кількість таких робіт значно збільшилась i намітилась тенденція до розвитку інтегративних «біопсихосоціальних» моделей депресії. Хоча такі моделі в деталях значно відрізняються одна від одної, проте у всіх них, як правило, значне місце займає гіпотеза взаємодії стресових середовищних факторів і індивідуальних рис схильності - гіпотеза діатезу - стресу.

При виявленні депресії та з'ясуванні іï впливу на психосоматичні розлади існують певні об'єктивні фактори, що ускладнюють виявлення i iii клінічну диференціацію. Достатньо лише виділити коморбідні зв'язки афективних розладів як 3 психічною, так i 3 соматичною 
патологією. Публікації в доступній формі, що узагальнюють сучасні погляди на цю проблему лише недавно почали.

Поширеність депресій в загальній популяції може різнитись залежно від використаних критеріїв ії оцінки, але показники, що наближаються до 5 \%, вважаються надійними. У хворих на ішемічну хворобу серця поширеність депресії, встановлених згідно критеріїв МКХ-10 сягає $20 \%$, тобто вона виявляється у кожного п'ятого [1].

Останнім часом з'являються дані про участь в патогенезі депресії регуляторних пептидів, передусім кортикотропіну резилінг-фактору (КРФ). Кортикотропін резилінг-фактор синтезується клітинами гіпоталамусу і призводить до виділення в кров з передньої долі гіпофізу адренокортикотропного гормону (АКТГ), який активізує викид кортизолу кірковою частиною надниркових залоз. В нормі кортизон гальмує функціонування гіпоталамо-гіпофізарної системи за механізмом негативного зворотного зв'язку. При депресії цей механізм порушується, в результаті у хворих помічено підвищений вміст АКТГ і кортизолу, причому концентрація кортизолу прямо корелює з важкістю депресії [2].

Депресія зустрічається в жінок удвічі частіше, ніж у чоловіків. Ці відмінності спостерігаються навіть після вирівнювання рівня достатку і соціального статусу. Вчені роблять декілька припущень 3 цього приводу. Одна з причин - гормональна. Жінкам доводиться переносити циклічні гормональні перепади, такі, як значні зміни рівня естрогену i прогістерону в передменструальний, післяродовий періоди i в менопаузі, які також пов'язані з депресивним настроєм [3]. Інша гіпотеза - психогенна, згідно якої головна причина в оволодінні стресом на ранніх стадіях його розвитку у чоловіків і жінок. Згідно 3 цією гіпотезою, жінки, що страждають на депресію, зациклюються на своєму відчаї, що, вірогідно, затягує цю хворобу. Чоловіки, що страждають депресією, навпаки, намагаються відволіктись від цього стану (наприклад, фізичною роботою), не заглиблюючись в цей депресивний стан. Хоча така стратегія не завжди є конструктивною [6].

Вченими при дослідженні викликаних потенціалів мозку хворих на депресію помічене підвищення активації кіркових зон, що регулюють негативні емоції i, відповідно, зниження активації областей, що пов'язані з регуляцією позитивних емоцій.

Важливу роль в патогенезі депресії відіграє неузгодженість рівня активації між передніми і задніми відділами мозку, які спеціалісти називають «поперечною функціональною блокадою» [4]. Підвищена активація переднього полюса кори може бути пусковим механізмом психоемоційної напруги і депресії. 
Негативізм викликаної активності, яка спостерігається у здорових людей в кінці навантаження, на думку науковців, $є$ нейрофізіологічним проявом процесу втоми в результаті монотонної діяльності, яка потребує активної уваги. Подібний негативізм спостерігається в осіб із депресією вже на початку діяльності, що вказує на деяку схожість нейрофізіологічних механізмів депресії 3 функціональним станом здорового мозку при втомі. Відсутність подальшого негативізму, викликаної активності у хворих в процесі виконання діяльності можна співставити з відсутністю у них клінічних ознак втоми. Навпаки, в кінці досліджень, на фоні незначної втоми, у хворих помічено значне покращення психічного стану: зменшення туги і тривоги, підвищення настрою, покращення зосередження, концентрації уваги. Покращувались також показники якості діяльності, хоча і були нижчими норми. Отже, під впливом тривалої стимуляції, в поєднанні з відповідною діяльністю у хворих на депресію спостерігалась помітна нормалізація функціонального стану мозку.

Згідно з сучасною класифікацією психічних і поведінкових розладів (МКХ-10), депресія характеризується трьома варіантами [1]: легкої, помірної та важкої форми - F32.0, F32.1 та F32.2 відповідно. В усіх трьох випадках хворий страждає від зниженого настрою, втрати інтересів і задоволення, зниження енергійності, що може призвести до підвищеної втомлюваності і зниженої активності. Помічається помітна втомлюваність навіть при незначних зусиллях. До інших симптомів відносяться: знижена здатність до зосередження і уваги, знижена самооцінка і відчуття самовпевненості в собі, ідеї провини, песимістичне бачення майбутнього, порушений сон, знижений апетит та ідеї і дії по самоушкодженню або суїциду [1].

Знижений настрій мало коливається впродовж декількох днів, і часто немає реакції на обставини, але можуть бути характерні коливання впродовж доби. В деяких випадках тривога, відчай і рухова ажитація часом можуть бути більш виражені, ніж депресія, а зміни настрою також можуть бути масковані додатковими симптомами; дратівливість, істеричність поведінки - іпохондричними ідеями. У випадках важкої форми депресії можуть бути помітними розлади когнітивних функцій уваги, пам'яті, здатності до виконання складних завдань. Тобто при депресії емоційні порушення $\epsilon$ первинними і домінуючими, а порівняно незначні когнітивні - вторинними, похідними. Тривалість депресивних епізодів зазвичай коливається в межах двох тижнів, але помітити іiі можна і в більш короткий період, якщо симптоми важкі і наступають швидко. 
Вченими помічено, що майже в усіх хворих 3 психосоматичними розладами $\epsilon$ і депресивні розлади, які характеризуються здебільшого слабко вираженими пригніченістю настрою, афектом туги, астенічними i тривожними проявами. Іноді помічені навіть різноманітні психопатологічні прояви граничного рівня при відносній частоті істеричних, сенестопатичних i іпохондричних розладах, ступінь прояву яких зазвичай незначний, що не дозволяє в більшості випадків враховувати ці порушення при класифікації психопатологічних станів.

Багато робіт присвячено вивченню співвідношень психічних i вегетативних порушень при різних захворюваннях, зокрема, ролі вегетативної нервової системи у виникненні афективних та інших психічних розладів. Робилась спроба розробки концепції «вісцерального мозку» [5], з визначенням мозкового субстрату емоцій. Вченими було встановлено, що вегетативні порушення здебільшого обумовлені психічними розладами, і мають психовегетативний характер, особливу роль при цьому відіграє тривожний афект, очевидна також роль депресії.

\section{Література:}

1. Международная классификация болезней (10-й пересмотр). Классификация психических и поведенческих расстройств. (Клинические описания и указания по диагностике). - Всемирная организация здравоохранения. Россия., Санкт-Петербург. - 1994. - 300 с.

2. Murphy B. Response to steroid suppression in major depression resistant 4o anti-depressant therapy / B. Murphy, V. Dhar, A. M. Ghadirian //. J Clin Psychopharmacol. - 1991. - № 11. - P. 121-126.

3. Seeman M. V. Psychopathology in women and men: Focus on female hormones / M. V. Seeman //. American Journal of Psychiatry. - 1997. $1647 \mathrm{p}$.

4. Психофизиология. Учебник для вузов/ Под. ред. Ю. И. Александрова. - СПб.: Питер, 2001. - 496 с.

5. Смулевич А. Б. Депрессии при соматических и психических заболеваниях / А. Б. Смулевич. - М.: МИА. $-2003-432$ с.

6. Харченко Д. М. Психосоматичні розлади. Теорії, методи діагностики, результати досліджень: навчальний посібник/ Д. М. Харченко. К. : Видавничий дім «Слово», 2015. - 280 с. 